\title{
The Role of the Exo-Xis Region in Oxidative Stress-Mediated Induction of Shiga Toxin-Converting Prophages
}

\author{
Katarzyna Licznerska, ${ }^{1}$ Aleksandra Dydecka, ${ }^{1}$ Sylwia Bloch, ${ }^{1}$ Gracja Topka, \\ Bożena Nejman-Faleńczyk, ${ }^{1}$ Alicja Węgrzyn, ${ }^{2}$ and Grzegorz Węgrzyn ${ }^{1}$ \\ ${ }^{1}$ Department of Molecular Biology, University of Gdańsk, Wita Stwosza 59, 80-308 Gdańsk, Poland \\ ${ }^{2}$ Laboratory of Molecular Biology (Affiliated with the University of Gdańsk), Institute of Biochemistry and Biophysics, \\ Polish Academy of Sciences, Wita Stwosza 59, 80-308 Gdańsk, Poland \\ Correspondence should be addressed to Grzegorz Węgrzyn; grzegorz.wegrzyn@biol.ug.edu.pl
}

Received 11 August 2015; Revised 22 September 2015; Accepted 28 September 2015

Academic Editor: Luciano Saso

Copyright (c) 2016 Katarzyna Licznerska et al. This is an open access article distributed under the Creative Commons Attribution License, which permits unrestricted use, distribution, and reproduction in any medium, provided the original work is properly cited.

Previous studies indicated that these genetic elements could be involved in the regulation of lysogenization and prophage induction processes. The effects were dramatic in Shiga toxin-converting phage $\Phi 24_{\mathrm{B}}$ after treatment with oxidative stress-inducing agent, hydrogen peroxide, while they were less pronounced in bacteriophage $\lambda$ and in both phages irradiated with UV. The hydrogen peroxide-caused prophage induction was found to be RecA-dependent. Importantly, in hydrogen peroxide-treated $E$. coli cells lysogenic for either $\lambda$ or $\Phi 24_{B}$, deletion of the exo-xis region resulted in a significant decrease in the levels of expression of the S.O.S. regulon genes. Moreover, under these conditions, a dramatic decrease in the levels of expression of phage genes crucial for lytic development (particularly xis, exo, $N$, cro, $O, Q$, and $R$ ) could be observed in $\Phi 24_{\mathrm{B}^{-}}$, but not in $\lambda$-bearing cells. We conclude that genes located in the exo-xis region are necessary for efficient expression of both host S.O.S regulon in lysogenic bacteria and regulatory genes of Shiga toxin-converting bacteriophage $\Phi 24_{B}$.

\section{Introduction}

Infection of humans by enterohemorrhagic Escherichia coli (EHEC) strains causes hemorrhagic colitis, and in some patients it may result in various complications, including, the most severe of them, the hemolytic-uremic syndrome and neurological dysfunctions [1-3]. The main causes of EHECmediated complications are Shiga toxins, produced by the infecting bacteria [4]. The severity of EHEC infections and significance of the medical problem related to them are exemplified by local outbreaks, occurring in various geographical regions around the world. One of the most famous of them took place in 2011 in Germany, where over 4,000 patients developed severe symptoms, and 54 died [5-10].

In EHEC strains, Shiga toxins are encoded by genes (called stx genes) located in genomes of prophages [11, 12]. The phages bearing stx genes are referred to as Shiga toxinconverting bacteriophages, and all of them belong to the family of lambdoid phages (with phage $\lambda$ serving as a paradigm)
[12]. stx genes are present between $Q$ antiterminator gene and the genes coding for proteins causing cell lysis; thus, in the lysogenic state, these genes are not transcribed [13-15] and Shiga toxins are not produced. Their expression is possible only after prophage induction $[11,12]$ which usually requires activation of the bacterial S.O.S. response, mediated by RecA protein, though RecA-independent induction of Shiga toxinconverting prophages by EDTA has also been reported [16].

During infection of human intestine by EHEC, the oxidative stress appears to be the most likely condition causing the bacterial S.O.S. response and subsequent induction of Shiga toxin-converting prophages [17]. In fact, it was demonstrated that hydrogen peroxide (which is produced by neutrophils as a response to infection) enhanced production of Shiga toxins by EHEC [18] due to oxidative stress-mediated induction of Shiga toxin-converting prophages $[19,20]$.

Since many antibiotics not only kill bacteria and inhibit their growth but also induce prophage lytic development, their use is not recommended when EHEC infection is 


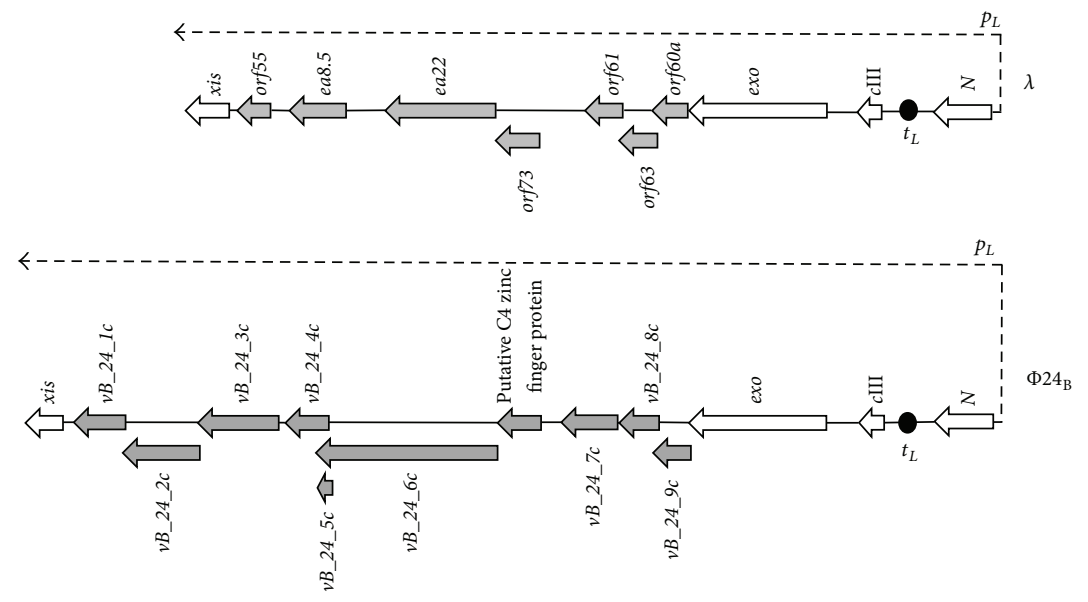

FIGURE 1: Schematic maps of the exo-xis regions of bacteriophages $\lambda$ and $\Phi 24_{\mathrm{B}}$. Genes from the exo-xis region are marked as thick grey arrows, and other genes are shown as thick open arrows. Directionality of transcription from $p_{L}$ promoter is indicated as thin dashed arrow. $t_{L 1}$ terminator is marked as black oval.

confirmed or even suspected (reviewed in [12]). Therefore, there are serious problems with treatment of patients, indicating that searching for new targets of potential therapies against Shiga toxin-producing bacteria is important. One might consider that such therapies should be focused on inhibition of Shiga toxin-converting prophage induction which would impair production of the EHEC virulence factor. All lambdoid phages, including Shiga toxin-converting bacteriophages, contain the $b$ region in their genomes which is dispensable for the development under standard laboratory conditions $[14,15]$. Inside this part of the phage genome, there is an evolutionarily conserved fragment, located between exo and $x i s$ genes and transcribed from $p_{L}$ promoter, called the exo-xis region (Figure 1). This region encompasses several genes and open reading frames whose functions in phage development are largely unknown, and only a few articles are available in the literature that focused on them. Nevertheless, some interesting observations have been reported. Namely, induction of expression of genes from the exo-xis region resulted in synchronization of the host cell cycle [21] and inhibition of host DNA replication [22]. Moreover, overexpression of these genes impaired lysogenization of $E$. coli by bacteriophage $\lambda$ [23] and enhanced induction of prophages $\lambda$ and $\Phi 24_{\mathrm{B}}$ (one of Shiga toxin-converting phages) [24]. Ea8.5 protein, encoded by a gene located in the exo-xis region, contains a fused homeodomain/zinc finger fold [25] which suggests a regulatory role for this protein. Interestingly, prophage induction with mitomycin $\mathrm{C}$ or hydrogen peroxide caused different expression patterns of genes from the exo$x i s$ region; such differences were observed in both phages, $\lambda$ and $\Phi 24_{\mathrm{B}}$ [26]. In this work, we used the deletion mutants to investigate the role of the exo-xis region in induction of $\lambda$ and $\Phi 24_{\mathrm{B}}$ prophages under oxidative stress conditions.

\section{Materials and Methods}

2.1. Bacteria and Bacteriophages. E. coli MG1655 strain [27] and its derivatives, used in this work, are listed in Table 1. Bacteria were routinely cultured in the Luria-Bertani (LB) medium at $30^{\circ} \mathrm{C}$ (most experiments) or $37^{\circ} \mathrm{C}$ (lysogenization and recombination procedures during construction of strains and SOS ChromoTest, according to the instructions of kits' manufacturers), under aerobic conditions. Where appropriate, the following antibiotics were added: chloramphenicol up to $20 \mu \mathrm{g} / \mathrm{mL}$, kanamycin up to $50 \mu \mathrm{g} / \mathrm{mL}$, and/or tetracycline up to $12.5 \mu \mathrm{g} / \mathrm{mL}$.

Bacteriophages $\lambda$ papa (from our collection) [26] and $\Phi 24_{B}(\Delta s t x 2:$ :cat) [28] were employed in this study. Phage suspensions were stored in the TM buffer $(10 \mathrm{mM}$ Tris- $\mathrm{HCl}$, $10 \mathrm{mM} \mathrm{MgSO}_{4}, \mathrm{pH} \mathrm{7.2)}$ at $4^{\circ} \mathrm{C}$.

The deletion mutants were constructed as described previously [29], by using the Quick and Easy E. coli Gene Deletion Kit (from Gene Bridges). The deletion of the indicated region was performed according to the manufacturer's protocol using primers listed in Table 2. In the first step, the targeted sequence has been replaced with the FRT-flanked kanamycin resistance cassette, and the selection marker was subsequently removed in the FLP-recombinase step, leaving only 87 nucleotides of the cassette in the place of the original sequence. Each deletion was confirmed by DNA sequencing.

Lysogenic strains were constructed according to the procedure described previously [24], with slight modifications. Briefly, host bacteria were cultured to $\mathrm{A}_{600}$ of 0.5 in LB medium supplemented with $\mathrm{MgSO}_{4}$ and $\mathrm{CaCl}_{2}$ (to final concentrations of $10 \mathrm{mM}$ each) at $37^{\circ} \mathrm{C}$ with shaking. At this point, one milliliter of the culture was withdrawn and centrifuged $(10 \mathrm{~min}, 2000 \times \mathrm{g})$. Pellet was washed twice with TCM buffer (10 mM Tris-HCl, pH 7.2, $10 \mathrm{mM} \mathrm{MgSO}_{4}, 10 \mathrm{mM}$ $\mathrm{CaCl}_{2}$ ) and then suspended in $1 \mathrm{~mL}$ of the same buffer. Next, bacteria were incubated for $30 \mathrm{~min}$ at $30^{\circ} \mathrm{C}$ and mixed with phage suspensions at multiplicity of infection (m.o.i.) $=5$. Mixtures of bacteria and phages were incubated in TMC buffer for $30 \mathrm{~min}$ at $30^{\circ} \mathrm{C}$; then serial dilutions were prepared in TM buffer (10 mM Tris- $\left.\mathrm{HCl}, 10 \mathrm{mM} \mathrm{MgSO}_{4} ; \mathrm{pH} 7.2\right)$, and the mixture was plated onto $\mathrm{LB}$ agar. Plates were incubated at $37^{\circ} \mathrm{C}$ overnight. Lysogens were verified by sensitivity to UV irradiation and confirmed by PCR with primers designed to amplify phage sequence (Table 3 ). 
TABLE 1: Escherichia coli strains.

\begin{tabular}{|c|c|c|}
\hline Strain & Genotype or relevant characteristics & Reference \\
\hline E. coli MG1655 & $\mathrm{F}^{-} \lambda^{-} i l v G r f b-50 r p h-1$ & [27] \\
\hline E. coli MG1655 $(\lambda)$ & MG1655 bearing $\lambda$ prophage & {$[24]$} \\
\hline E. coli MG1655 ( $\lambda \Delta$ exo-xis $)$ & $\begin{array}{l}\text { MG1655 bearing } \lambda \text { prophage with deletion of all orfs and genes } \\
\text { localized between genes exo and xis }\end{array}$ & This study, by recombination \\
\hline E. coli MG1655 $(\lambda \Delta$ orfs $)$ & $\begin{array}{l}\text { MG1655 bearing } \lambda \text { prophage with deletion of orf60a, orf } 63 \text {, } \\
\text { orf } 61 \text {, and orf } 73\end{array}$ & This study, by recombination \\
\hline E. coli MG1655 $(\lambda \Delta$ orf60a $)$ & MG1655 bearing $\lambda$ prophage with deletion of orf $60 a$ & This study, by recombination \\
\hline E. coli MG1655 ( $\lambda \Delta$ orf63) & MG1655 bearing $\lambda$ prophage with deletion of orf63 & This study, by recombination \\
\hline E. coli MG1655 $(\lambda \Delta$ orf61) & MG1655 bearing $\lambda$ prophage with deletion of orf 61 & This study, by recombination \\
\hline E. coli MG1655 ( $\lambda \Delta$ orf73) & MG1655 bearing $\lambda$ prophage with deletion of orf 73 & This study, by recombination \\
\hline E. coli MG1655 ( $\lambda \Delta e a 22)$ & MG1655 bearing $\lambda$ prophage with deletion of ea22 & This study, by recombination \\
\hline E. coli MG1655 ( $\lambda \Delta e a 8.5)$ & MG1655 bearing $\lambda$ prophage with deletion of $e a 8.5$ & This study, by recombination \\
\hline E. coli MG1655 (Ф24 $\left.4_{\mathrm{B}}\right)$ & MG1655 bearing $\Phi 24_{\mathrm{B}}$ prophage & {$[24]$} \\
\hline E. coli MG1655 (Ф24 ${ }_{\mathrm{B}} \Delta$ exo-xis $)$ & $\begin{array}{l}\text { MG1655 bearing } \Phi 24_{\mathrm{B}} \text { prophage with deletion of all orfs and } \\
\text { genes localized between genes exo and xis }\end{array}$ & This study, by recombination \\
\hline E. coli MG1655 ( $\Phi 24_{\mathrm{B}} \Delta$ orfs $)$ & $\begin{array}{l}\text { MG1655 bearing } \Phi 24_{B} \text { prophage with deletion of } 4 \text { orfs being } \\
\text { homologues of } \lambda \text { orf } 60 a, \lambda \operatorname{orf} 63, \lambda \text { orf } 61 \text {, and } \lambda \text { orf } 73\end{array}$ & This study, by recombination \\
\hline E. coli MG1655 $\left(\Phi 24_{\mathrm{B}} \Delta\right.$ orf60a $)$ & $\begin{array}{l}\text { MG1655 bearing } \Phi 24_{B} \text { prophage with deletion of vb_24 } 4_{B}-9 c \text {, the } \\
\text { homologue of } \lambda \text { orf } 60 a\end{array}$ & This study, by recombination \\
\hline E. coli MG1655 (Ф24 ${ }_{\mathrm{B}} \Delta$ orf63) & $\begin{array}{l}\text { MG1655 bearing } \Phi 24_{B} \text { prophage with deletion of vb_24 } 4_{B}-8 c \text {, the } \\
\text { homologue of } \lambda \text { orf } 63\end{array}$ & This study, by recombination \\
\hline E. coli MG1655 $\left(\Phi 24_{\mathrm{B}} \Delta\right.$ orf61) & $\begin{array}{l}\text { MG1655 bearing } \Phi 24_{B} \text { prophage with deletion of vb } 24_{B}-7 c \text {, the } \\
\text { homologue of } \lambda \text { orf } 61\end{array}$ & This study, by recombination \\
\hline E. coli MG1655 (Ф24 ${ }_{\mathrm{B}} \Delta$ orf 73$)$ & $\begin{array}{l}\text { MG1655 bearing } \Phi 24_{\text {B }} \text { prophage with deletion of the sequence } \\
\text { of putative C4 zinc finger protein, the homologue of } \lambda \text { orf } 73\end{array}$ & This study, by recombination \\
\hline E. coli MG1655 $\left(\Phi 24_{\mathrm{B}} \Delta e a 22\right)$ & $\begin{array}{l}\text { MG1655 bearing } \Phi 24_{B} \text { prophage with deletion of vb_24 } 4_{B}-6 \mathrm{c} \text {, the } \\
\text { analogue of } \lambda e a 22\end{array}$ & This study, by recombination \\
\hline E. coli MG1655recA13 & MG1655 but recA13 & [33] \\
\hline E. coli MG1655recA13 $(\lambda)$ & MG1655recA13 bearing $\lambda$ prophage & This study, by lysogenization \\
\hline E. coli MG1655recA13 ( $\lambda \Delta$ exo-xis $)$ & $\begin{array}{l}\text { MG1655recA13 bearing } \lambda \text { prophage with deletion of all orfs and } \\
\text { genes localized between genes exo and xis }\end{array}$ & This study, by lysogenization \\
\hline E. coli MG1655recA13 $\left(\Phi 24_{\mathrm{B}}\right)$ & MG1655recA13 bearing $\Phi 24_{\mathrm{B}}$ prophage & This study, by lysogenization \\
\hline E. coli MG1655recA13 $\left(\Phi 24_{\mathrm{B}} \Delta\right.$ exo-xis $)$ & $\begin{array}{l}\text { MG1655recA13 bearing } \Phi 24_{\mathrm{B}} \text { prophage with deletion of all orfs } \\
\text { and genes localized between genes exo and xis }\end{array}$ & This study, by lysogenization \\
\hline E. coli $\mathrm{PQ} 37$ & 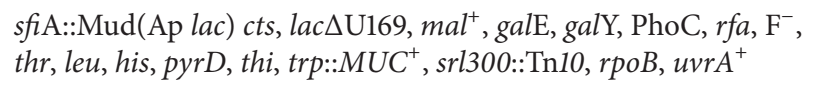 & {$[31]$} \\
\hline E. coli PQ37 $(\lambda)$ & PQ37 bearing $\lambda$ prophage & This study, by lysogenization \\
\hline E. coli $\mathrm{PQ} 37(\lambda \Delta$ exo-xis $)$ & $\begin{array}{l}\text { PQ37 bearing } \lambda \text { prophage with deletion of all orfs and genes } \\
\text { localized between genes exo and xis }\end{array}$ & This study, by lysogenization \\
\hline E. coli PQ37 $\left(Ф 24_{\mathrm{B}}\right)$ & PQ37 bearing $\Phi 24_{\mathrm{B}}$ prophage & This study, by lysogenization \\
\hline E. coli $\mathrm{PQ} 37\left(\Phi 24_{\mathrm{B}} \Delta e x o-x i s\right)$ & $\begin{array}{l}\text { PQ37 bearing } \Phi 24_{\text {B }} \text { prophage with deletion of all orfs and genes } \\
\text { localized between genes exo and xis }\end{array}$ & This study, by lysogenization \\
\hline
\end{tabular}

2.2. Phage Lytic Development after Prophage Induction. Bacteria lysogenic with tested phages were cultured in LB medium at $30^{\circ} \mathrm{C}$ to $\mathrm{A}_{600}$ of 0.1. Two induction agents were tested: $\mathrm{H}_{2} \mathrm{O}_{2}(1 \mathrm{mM})$ and UV irradiation $\left(50 \mathrm{~J} / \mathrm{m}^{2}\right.$; this dose was achieved by $20 \mathrm{sec}$ incubation of the bacterial suspensions in Petri dishes under UV lamp hanged $17 \mathrm{~cm}$ above the laboratory table). At indicated times after induction, samples of bacterial cultures were harvested, and $30 \mu \mathrm{L}$ of chloroform was added to $0.5 \mathrm{~mL}$ of each sample. The mixture was vortexed and centrifuged for $5 \mathrm{~min}$ in a microcentrifuge.
Then, serial dilutions were prepared in TM buffer, and phage titer (number of phages per $\mathrm{mL}$ ) was determined by spotting $2.5 \mu \mathrm{L}$ of each dilution of the phage lysate on a freshly prepared LB agar (1.5\%) or LB agar with $2.5 \mu \mathrm{g} / \mathrm{mL}$ chloramphenicol (according to a procedure described previously [30]), with a poured mixture of $1 \mathrm{~mL}$ of the indicator E. coli MG1655 strain culture and $2 \mathrm{~mL}$ of $0.7 \%$ nutrient agar (prewarmed to $45^{\circ} \mathrm{C}$ ), supplemented with $\mathrm{MgSO}_{4}$ and $\mathrm{CaCl}_{2}$ (to a final concentration of $10 \mathrm{mM}$ each). When fullplate titration was used, $0.1 \mathrm{~mL}$ of phage lysate dilutions was 


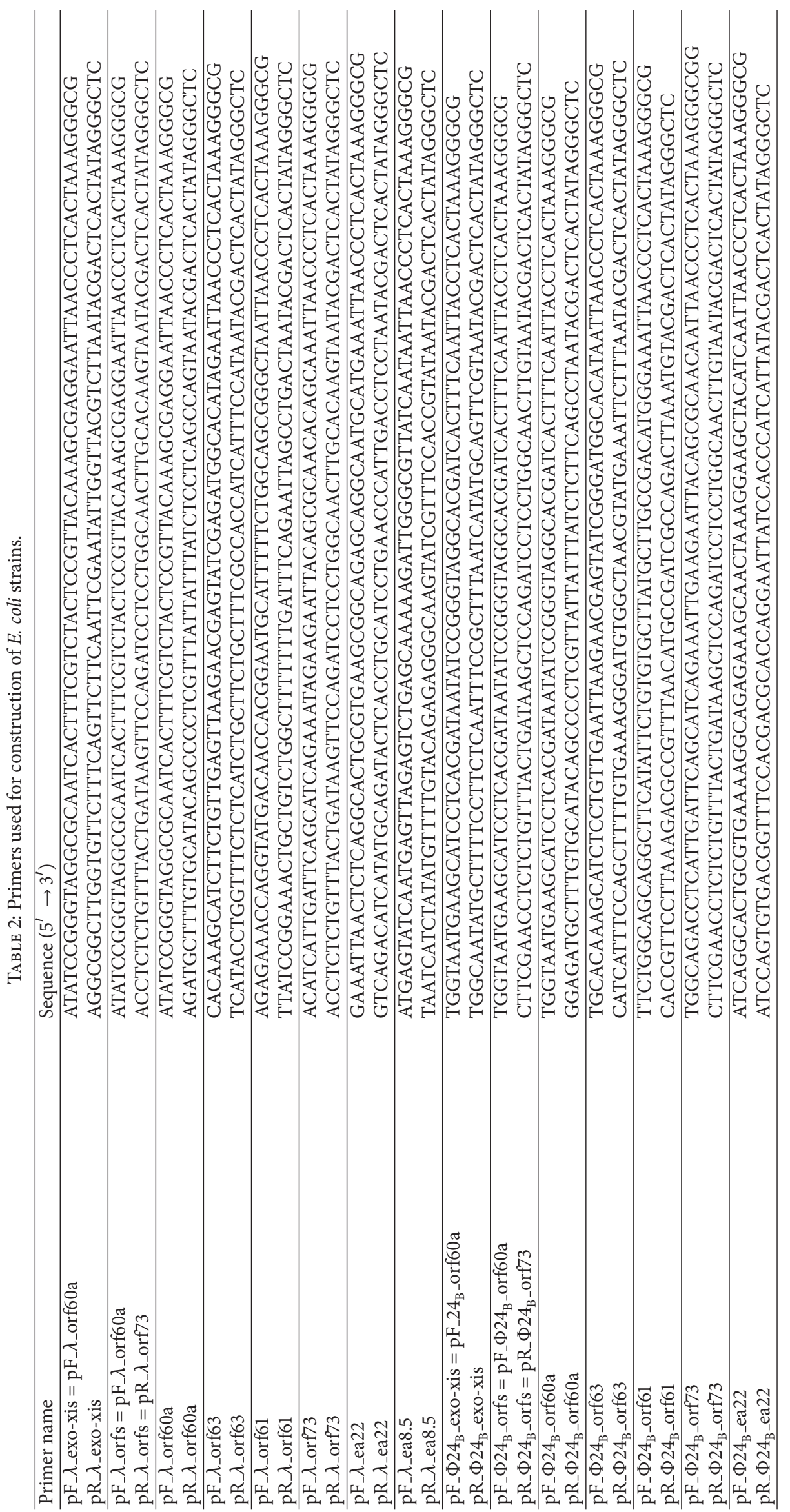


TABle 3: Primers used for PCR.

\begin{tabular}{|c|c|c|c|}
\hline \multicolumn{2}{|c|}{ Primers for bacterial sequences } & \multicolumn{2}{|c|}{ Primers for phage sequences } \\
\hline Name & Sequence $\left(5^{\prime} \rightarrow 3^{\prime}\right)$ & Name & Sequence $\left(5^{\prime} \rightarrow 3^{\prime}\right)$ \\
\hline pF_recA & AGATTTCGACGATACGGCCC & $\mathrm{pF} \_\lambda \_$int & TTTGATTTCAATTTTGTCCCACT \\
\hline pR_recA & AACCATCTCTACCGGTTCGC & $\mathrm{pR} \_\lambda$ int & ACCATGGCATCACAGTATCG \\
\hline pF_lexA & ATGGATGGTGACTTGCTGGC & $\mathrm{pF} \_\lambda \_\mathrm{xis}$ & TACCGCTGATTCGTGGAACA \\
\hline pR_lexA & TTCGTCATCAATACGTGCGAC & $\mathrm{pR} \lambda \lambda_{\text {Xis }}$ & GGGTTCGGGAATGCAGGATA \\
\hline pF_ssb & ATCGAAGGTCAGCTGCGTAC & $\mathrm{pF} \_\lambda \_$exo & TGCCGTCACTGCATAAACC \\
\hline pR_ssb & CGACTTCTGTGGTGTAGCGA & pR_ $\lambda \_$exo & TCTATCGCGACGAAAGTATGC \\
\hline pF_recF & CGATACCGGCGCTATACTCC & $\mathrm{pF} \_\lambda_{-} \mathrm{cIII}$ & ATTCTTTGGGACTCCTGGCTG \\
\hline pR_recF & TTACGAACAGCTACGCCCG & pR_$\lambda \_c I I I$ & GTAAATTACGTGACGGATGGAAAC \\
\hline pF_rpoD & GAATCTGAAATCGGGCGCAC & $\mathrm{pF} \lambda \_\mathrm{N}$ & CTCGTGATTTCGGTTTGCGA \\
\hline pR_rpoD & GTCAACAGTTCAACGGTGCC & $\mathrm{pR} \_\lambda \_\mathrm{N}$ & AAGCAGCAAATCCCCTGTTG \\
\hline pF_rpoH & GCTTTGGTGGTCGCAACTTT & $\mathrm{pF} \lambda_{-} \mathrm{cI}$ & ACCTCAAGCCAGAATGCAGA \\
\hline pR_rpoH & TCGCCGTTCACTGGATCAAA & $\mathrm{pR} \_\lambda_{-} \mathrm{cI}$ & CCAAAGGTGATGCGGAGAGA \\
\hline pF_rpoS & TTGCTCTGCGATCTCTTCCG & pF_ $\lambda \_$cro & ATGCGGAAGAGGTAAAGCCC \\
\hline pR_rpoS & GAACGTTTACCTGCGAACCG & $\mathrm{pR} \_\lambda_{-} \mathrm{cro}$ & TGGAATGTGTAAGAGCGGGG \\
\hline pF_uvrA & GTCCATATCCGCCACTACCG & pF_ $\lambda_{-}$cII & TCGCAATGCTTGGAACTGAGA \\
\hline pR_uvrA & TTACCCAACGTCTTGCCGAG & $\mathrm{pR} \lambda \lambda_{-} \mathrm{cII}$ & СССТСТTCСАCСТGCTGATC \\
\hline $\mathrm{pF}$ ftsK & ACAAACCGTTTATCTGCGCG & $\mathrm{pF} \lambda \lambda_{-} \mathrm{O}$ & AATTCTGGCGAATCCTCTGA \\
\hline pR_ftsK & ATCTTTACCCAGCACCACGG & $\mathrm{pR} \_\lambda \_\mathrm{O}$ & GAATTGCATCCGGTTT \\
\hline pF_16SrRNA & CCTTACGACCAGGGCTACAC & $\mathrm{pF} \lambda_{-} \mathrm{Q}$ & TTCTGCGGTAAGCACGAAC \\
\hline pR_16SrRNA & TTATGAGGTCCGCTTGCTCT & pR_$\lambda \_Q$ & TGCATCAGATAGTTGATAGCCTTT \\
\hline & & $\mathrm{pF} \_\lambda \_\mathrm{R}$ & ATCGACCGTTGCAGCAATA \\
\hline & & $\mathrm{pR} \_\lambda \_\mathrm{R}$ & GCTCGAACTGACCATAACCAG \\
\hline & & pF_Ф24 ${ }_{B}$ int & CAGTTGCCGGTATCCCTGT \\
\hline & & pR_Ф24 $4_{B}$-int & TGAGGCTTTCTTGCTTGTCA \\
\hline & & pF_ $\Phi 24_{B}$ xis & TATCGCGCCGGATGAGTAAG \\
\hline & & pR_Ф24 $4_{B}$ xis & CGCACAGCTTTGTATAATTTGCG \\
\hline & & pF_Ф24 $4_{B}-$ exo & TGCCGTCACTGCATAAACC \\
\hline & & pR_Ф24 $4_{B}$ exo & TCTATCGCGACGAAAGTATGC \\
\hline & & pF_Ф24 ${ }_{B}-\mathrm{cIII}$ & ATTCTTTGGGACTCCTGGCTG \\
\hline & & pR_Ф24 ${ }_{B}-\mathrm{CIII}$ & GTAAATTACGTGACGGATGGAAAC \\
\hline & & pF_Ф24 ${ }_{B}-\mathrm{N}$ & AGGCGTTTCGTGAGTACCTT \\
\hline & & pR_Ф24 ${ }_{B}-\mathrm{N}$ & TTACACCGCCСТACTCTAAGC \\
\hline & & pF_Ф24 ${ }_{B}-\mathrm{CI}$ & TGCTGTCTCCTTTCACACGA \\
\hline & & pR_Ф24 $4_{B}-\mathrm{cI}$ & GCGATGGGTGGCTCAAAATT \\
\hline & & pF_ $\Phi 24_{B_{-}}$cro & CGAAGGCTTGTGGAGTTAGC \\
\hline & & pR_Ф24 ${ }_{B}$-cro & GTCTTAGGGAGGAAGCCGTT \\
\hline & & pF_Ф24 ${ }_{B}-\mathrm{cII}$ & TGATCGCGCAGAAACTGATTTAC \\
\hline & & pR_Ф24 $4_{B}-\mathrm{cII}$ & GACAGCCAATCATCTTTGCCA \\
\hline & & pF_Ф $24_{B}-\mathrm{O}$ & AAGCGAGTTTGCCACGAT \\
\hline & & pR_Ф24 ${ }_{\mathrm{B}-} \mathrm{O}$ & GAACCCGAACTGCTTACCG \\
\hline & & pF_Ф24 $4_{B}$ Q & GGGAGTGAGGCTTGAGATGG \\
\hline & & pR_Ф24 ${ }_{B-} Q$ & TACAGAGGTTCTCCCTCCCG \\
\hline & & pF_Ф24 ${ }_{B}-\mathrm{R}$ & GGGTGGATGGTAAGCCTGT \\
\hline & & pR_Ф24 $4_{B}-\mathrm{R}$ & TAACCCGGTCGCATTTTTC \\
\hline
\end{tabular}

plated onto LB agar. Plates were incubated at $37^{\circ} \mathrm{C}$ overnight. Analogous experiment but without induction agents (control experiments), which allows estimation of effects of spontaneous prophage induction, was performed with each lysogenic strain. The relative phage titer, expressed as plaque forming units (pfu)/mL, was calculated by subtracting the values obtained in the control experiment from the values determined in the main experiment, and as a consequence it represents the ratio of phage titers in induced and noninduced cultures. Each experiment was repeated three times. 
2.3. The S.O.S. Assay. The S.O.S. assay was performed using the SOS-ChromoTest Kit (Environmental Bio-Detection Products Inc.), following the manufacturer's protocol and using provided 4-nitro-quinoline oxide (4-NQO) as a positive reference standard, and $1 \mathrm{mM} \mathrm{H}_{2} \mathrm{O}_{2}$ and $\mathrm{UV}$ irradiation $\left(50 \mathrm{~J} / \mathrm{m}^{2}\right)$ as tested inducers of the S.O.S. response [31, 32]. In the case of UV light irradiation, the production of $\beta$ galactosidase was evaluated immediately after the exposure, without $2 \mathrm{~h}$ incubation at $37^{\circ} \mathrm{C}$ (recommended by the manufacturer), as, without this modification, the visual detection of the blue color was not possible due to rapid S.O.S. response after UV irradiation. Before use, the SOSChromoTest bacterial strain (E. coli PQ37, provided with the kit) was lysogenized by following phages: $\lambda, \lambda \Delta$ exo-xis, $\Phi 24_{B}$, or $\Phi 24_{\mathrm{B}} \Delta$ exo-xis, according to procedure described above.

2.4. Preparation of RNA and cDNA from Bacteria. For the isolation of total RNA, the previously described [26] procedure was employed. Briefly, the prophage induction was performed with $1 \mathrm{mM} \mathrm{H}_{2} \mathrm{O}_{2}$ or UV irradiation (at the dose of $50 \mathrm{~J} / \mathrm{m}^{2}$ ). Following induction, the samples were withdrawn at indicated times and the growth of bacteria was inhibited by the addition of $\mathrm{NaN}_{3}$ (Sigma-Aldrich) to a final concentration of $10 \mathrm{mM}$. Total RNA was isolated from $10^{9}$ bacterial cells by using the High Pure RNA Isolation Kit (Roche Applied Science). Bacterial genomic DNA carryover was removed by incubation with TURBO DNase from TURBO DNA-free Kit (Life Technologies) for $60 \mathrm{~min}$ at $37^{\circ} \mathrm{C}$, according to the manufacturer's guidelines. To evaluate the quality and quantity of the isolated RNA, a NanoDrop spectrophotometer was employed, considering the absorbance ratio (which should be $1.8 \leq$ A260/A280 $\leq 2.0$ ). Moreover, band patterns of total RNA were visualized by electrophoresis. The absence of DNA from RNA samples was controlled by PCR amplification and by real-time PCR amplification (all analyzed genes were tested). RNA preparations were stored at $-80^{\circ} \mathrm{C}$. cDNA was obtained with Transcriptor Reverse Transcriptase and random hexamer primers (Roche Applied Science), using total RNA samples $(1.25 \mu \mathrm{g})$ as templates. cDNA reaction mixtures were diluted 10 -fold for use in real-time PCR.

2.5. Real-Time PCR Assay and Data Analysis. The patterns of genes' expression were determined by quantitative real-time reverse transcription-PCR (qRT-PCR), using the LightCycler 480 Real-Time PCR System (Roche Applied Science) and cDNA samples from lysogenic bacteria. Transcripts of tested phage and bacterial genes were compared in parallel to $16 S$ rRNA housekeeping gene (according to a procedure described previously [34]), whose expression was found to be constant. Primers were developed by Primer3web version 4.0.0 and produced by Sigma-Aldrich or GENOMED. The transcriptional analysis of phage and bacterial genes from lysogenic strains was performed with primers presented in Table 3. Real-time PCR amplifications were carried out for 55 cycles in $20 \mu \mathrm{L}$ reaction volume, using LightCycler 480 SYBR Green I Master (Roche Applied Science) as a fluorescent detection dye. Reactions were performed in Roche 96-well plates containing $10 \mu \mathrm{L} 2 \mathrm{x}$ SYBR Green I
Master Mix, $6.25 \mathrm{ng} / \mu \mathrm{L} \mathrm{cDNA}$, and $200 \mathrm{nM}$ of each genespecific primer (Table 3). Relative quantification assays were performed with cDNA of $16 \mathrm{~S}$ rRNA and phage/bacterial genes multiplex assay. All templates were amplified using the following program: incubation at $95^{\circ} \mathrm{C}$ for $5 \mathrm{~min}$, followed by 55 cycles of $95^{\circ} \mathrm{C}$ for $10 \mathrm{~s}, 60^{\circ} \mathrm{C}$ for $15 \mathrm{~s}$, and $72^{\circ} \mathrm{C}$ for $15 \mathrm{~s}$. No template control was included with each run. The specificity of amplified products was examined by melting curve analysis immediately after the final PCR cycle and confirmed by gel electrophoresis. Each experiment was conducted in triplicate.

The relative changes in gene expression revealed by quantitative real-time PCR experiments were analyzed using the calibrator, normalizing relative quantification method with efficiency correction (called the E-Method). This method has been used and described in detail previously [26, 29, 35]. The values obtained at time 0 (representing the conditions of spontaneous prophage induction) were used as calibrators. Thus, the following equation was employed to calculate the final results:

Normalized relative ratio

$$
=\frac{E_{t}{ }^{\mathrm{CT}(t)} \text { calibrator-CT }(t) \text { sample }}{E_{r}{ }^{\mathrm{CT}}(r) \text { calibrator-CT }(r) \text { sample }},
$$

where $t$ is target and $r$ is reference.

2.6. In Silico Analyses. The multiple sequence alignment was performed using the ClustalW algorithm available at the website http://www.genome.jp/tools/clustalw/. The Pfam protein families database [36], available at the website http://pfam .xfam.org/, was used to identify protein domains.

\section{Results and Discussion}

3.1. Deletion of the Exo-Xis Region Impairs $\Phi 24_{\mathrm{B}}$ but Not $\lambda$ Prophage Induction after Treatment with Hydrogen Peroxide. Until now, all in vivo studies on effects of the exo-xis region on host or phage development were performed with the use of strains overexpressing genes from this region [21-24, 26]. In this work, we have constructed a series of bacteriophage $\lambda$ and $\Phi 24_{\mathrm{B}}$ mutants with deletions of either the whole exo-xis region or individual genes or open reading frames (Table 1). When wild-type $\lambda$ and $\Phi 24_{\mathrm{B}}$ prophages were induced by UV irradiation (employed in this work as positive control conditions causing effective prophage induction) or hydrogen peroxide treatment of the lysogenic cells, efficiencies of induction and further phage lytic development were comparable in both phages, though some differences were observed in the duration of the lag phase of the phage development (Figure 2). Induction of $\lambda \Delta$ exo-xis mutant with UV irradiation was similar to that observed for the wild-type $\lambda$, and treatment with hydrogen peroxide caused only a slight delay in the mutant phage development. The decrease in the phage titer at later times of the experiments is characteristic for $\lambda$ and most probably arises from adsorption of the progeny virions on fragments of disrupted cell envelopes [15, 24]. However, induction of $\Phi 24_{\mathrm{B}} \Delta$ exo-xis prophage by UV irradiation was less efficient than that of the wild-type $\Phi 24_{\mathrm{B}}$, and induction 
$\lambda$

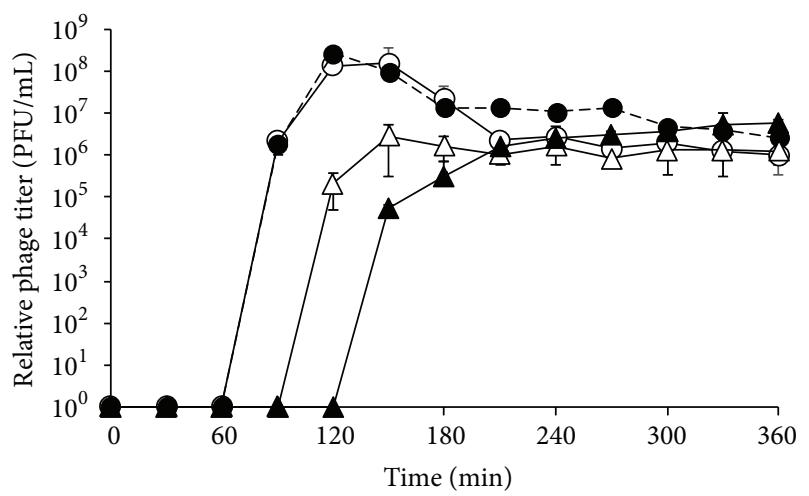

(a)

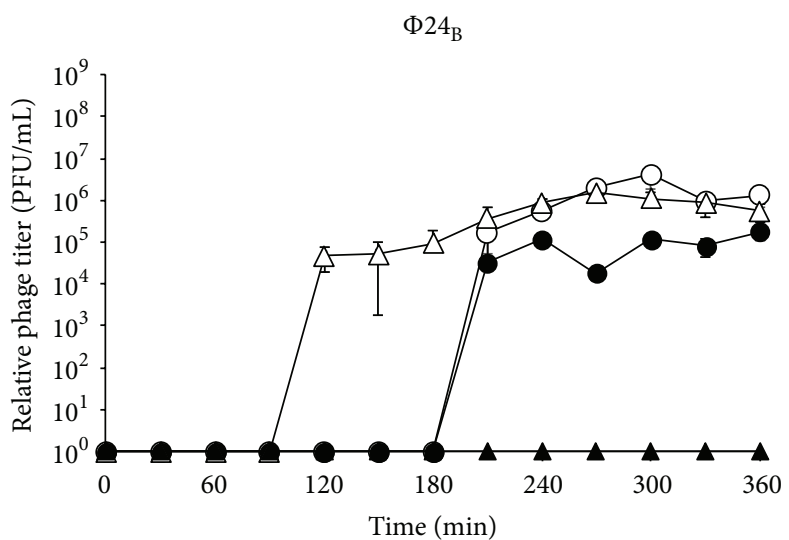

(b)

FIGURE 2: Lytic development of bacteriophages $\lambda$ (a) and $\Phi 24_{\mathrm{B}}$ (b), either wild-type (open symbols) or $\Delta$ exo-xis (closed symbols), after induction of lysogenic E. coli MG1655 with UV irradiation ( $50 \mathrm{~J} / \mathrm{m}^{2}$, circles) or hydrogen peroxide (1 mM, triangles). The presented results are mean values from 3 independent experiments (biological samples), with error bars indicating SD. Statistically significant differences ( $p<0.05$ in $t$-test) between wild-type and $\Delta$ exo-xis phages were found at times 270,300 , and $360 \mathrm{~min}$ of experiments with hydrogen peroxide and at $270,300,330$, and $360 \mathrm{~min}$ of experiments with UV for $\lambda$ and at times 120, 240, 270, 300, 330, and 360 min of experiments with hydrogen peroxide and at 270, 300, 330, and 360 min of experiments with UV for $\Phi 24_{B}$.

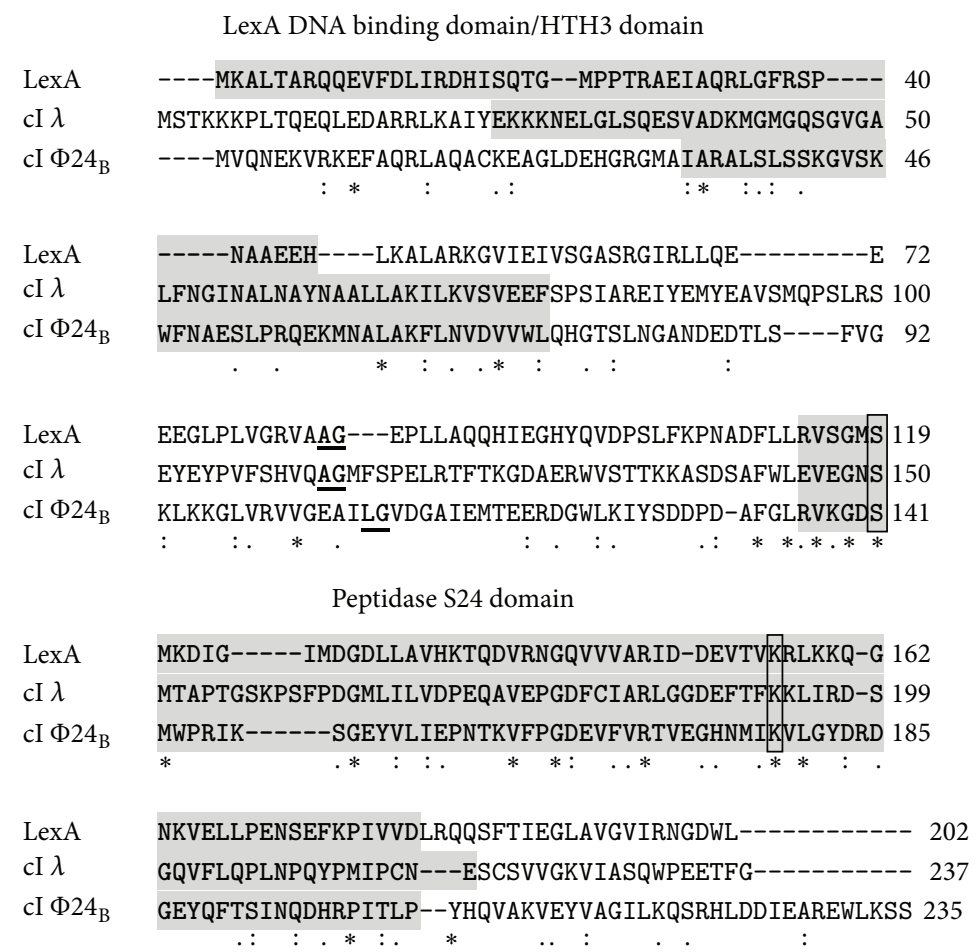

FIGURE 3: Alignment of amino acid sequences of E. coli LexA protein and cI repressors of bacteriophages $\lambda$ and $\Phi 24_{B}$. Specific protein domains are indicated by grey background. Self-cleavage sites are underlined (two amino acid residues between which the cleavage occurs). The active sites of the peptidase domains are framed. Symbols under the sequence alignment indicate conserved sequence $(*)$, conservative mutations (:), semiconservative mutations (.), and nonconservative mutations ().

of the mutant by hydrogen peroxide was severely impaired (Figure 2). More detailed analyses, based on the full-plate phage titration method, allowing detection of $10 \mathrm{pfu} / \mathrm{mL}$ (see Section 2 for details), indicated that the number of pfu per $\mathrm{mL}$ of $\Phi 24_{\mathrm{B}} \Delta$ exo-xis phage after induction with hydrogen peroxide was at the same range $\left(10^{3} / \mathrm{mL}\right)$ as that measured without specific induction (i.e., representing efficiency of spontaneous prophage induction). Nevertheless, the titer of $\Phi 24_{\mathrm{B}} \Delta$ exo-xis measured at 240 and $360 \mathrm{~min}$ after induction was $9.0 \pm 0.2 \times 10^{3}$ and $7.9 \pm 0.9 \times 10^{3}$, respectively, that 

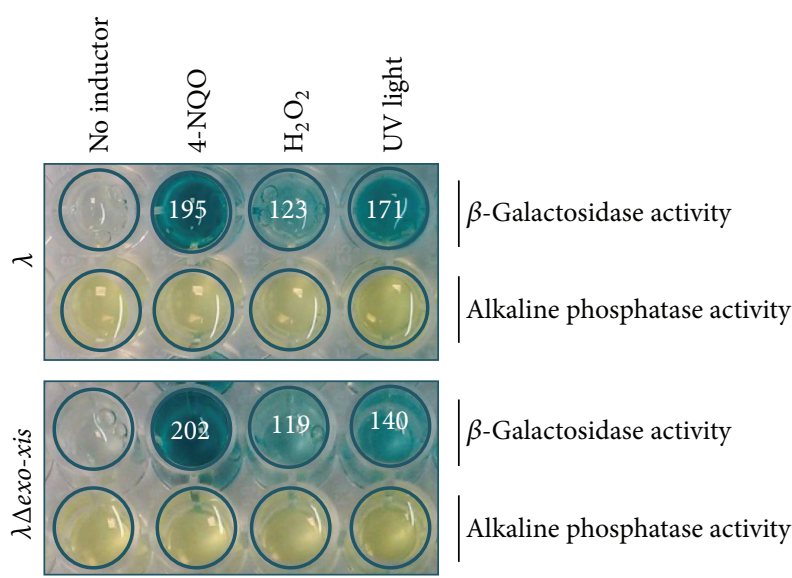

$\beta$-Galactosidase activity

Alkaline phosphatase activity

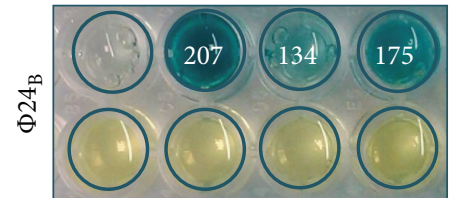

$\beta$-Galactosidase activity

Alkaline phosphatase activity

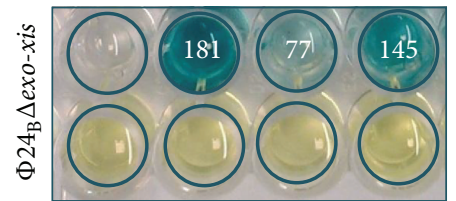

$\beta$-Galactosidase activity

Alkaline phosphatase activity

FIgURE 4: Induction of the S.O.S. response in E. coli PQ37 lysogenic with $\lambda, \lambda \Delta e x o-x i s, \Phi 24_{\mathrm{B}}$, or $\Phi 24_{\mathrm{B}} \Delta$ exo-xis, treated with 4-NQO (4nitro-quinoline oxide, positive control), $\mathrm{H}_{2} \mathrm{O}_{2}(1 \mathrm{mM})$, or UV $\left(50 \mathrm{~J} / \mathrm{m}^{2}\right)$, using the SOS ChromoTest. $\beta$-Galactosidase activity (identified by the blue spots) represents induction of the S.O.S. regulon. Alkaline phosphatase activity (identified by yellow spots) evaluates viability of tested bacteria. Quantification of $\beta$-galactosidase activity was performed by densitometry, using the ImageJ software (available at http://imagej.nih.gov/ij/index.html). The results (in arbitrary units reflecting value $=1$ ascribed to samples with no inductor), presented as numbers inside the corresponding spots, are mean values from three measurements (with $\mathrm{SD}<10 \%$ in each case). All these values were significantly ( $p<0.001$ in $t$-test) higher than that in the control experiments with no inductor. When $\Delta$ exo-xis mutants were compared to wild-type phages, the only significant difference $\left(p<0.05\right.$ in $t$-test) occurred between $\Phi 24_{\mathrm{B}}$ and $\Phi 24_{\mathrm{B}} \Delta$ exo-xis lysogens induced with hydrogen peroxide.

is, still 3-4 times higher than that without induction, which was $2.1 \pm 0.3 \times 10^{3}$ and $2.6 \pm 0.4 \times 10^{3}$, respectively (note that the titer of the wild-type $\Phi 24_{\mathrm{B}}$ after prophage induction was several orders of magnitude higher than that without induction, Figure 2).

Deletions of individual genes and open reading frames from the exo-xis region in $\Phi 24_{\mathrm{B}}$ did not affect significantly the phage titer. However, such deletions resulted in delays in prophage induction by hydrogen peroxide (Table 4 ). Interestingly, when prophage induction was stimulated by UV irradiation, such effect was not observed, and in some cases even more rapid induction of the mutant prophages occurred. In bacteriophage $\lambda$, only slight effects of deletions of individual genes and open reading frames were detected (Table 4).

We conclude that the genes and open reading frames from the exo-xis region play important roles in the regulation of lambdoid prophage induction, as deletions of the whole region or single loci caused significant changes in efficiency and timing of this process. The effects of mutations are more pronounced in Shiga toxin-converting phage $\Phi 24_{\mathrm{B}}$ than in $\lambda$ and in lysogenic $E$. coli cells treated with hydrogen peroxide than in UV-irradiated ones. Thus, the exo-xis region seems to be particularly important for $\Phi 24_{\text {B }}$ phage under conditions of the oxidative stress, the most likely conditions causing Shiga toxin-converting prophage induction during infection with EHEC.

\subsection{Hydrogen Peroxide-Mediated Prophage Induction Is a} RecA-Dependent Process. Efficient induction of lambdoid prophages is a RecA-dependent process due to a molecular mimicry between the phage cI repressor and the hostencoded LexA repressor which is self-cleaved after stimulation by the activated form of RecA protein under the S.O.S. response conditions [12-15]. Such a mimicry is well known for bacteriophage $\lambda$ cI protein and LexA [12, 13], and we found that both domain structure and amino acid residues crucial for the self-cleavage are also conserved in cI repressor of phage $24_{B}$ (Figure 3) (note that cI sequence of $24_{B}$ is identical to that of another Shiga toxin-converting bacteriophage, $933 \mathrm{~W}$ [37]). Nevertheless, since RecA-independent induction of Shiga toxin-converting prophages has also been reported [16], we asked whether hydrogen peroxide-caused prophage induction depends on the activation of the S.O.S. response.

When testing $\mathrm{H}_{2} \mathrm{O}_{2}$ - or UV-dependent induction of prophages $\lambda, \lambda \Delta$ exo-xis, $\Phi 24_{\mathrm{B}}$, and $\Phi 24_{\mathrm{B}} \Delta$ exo-xis in recA13 

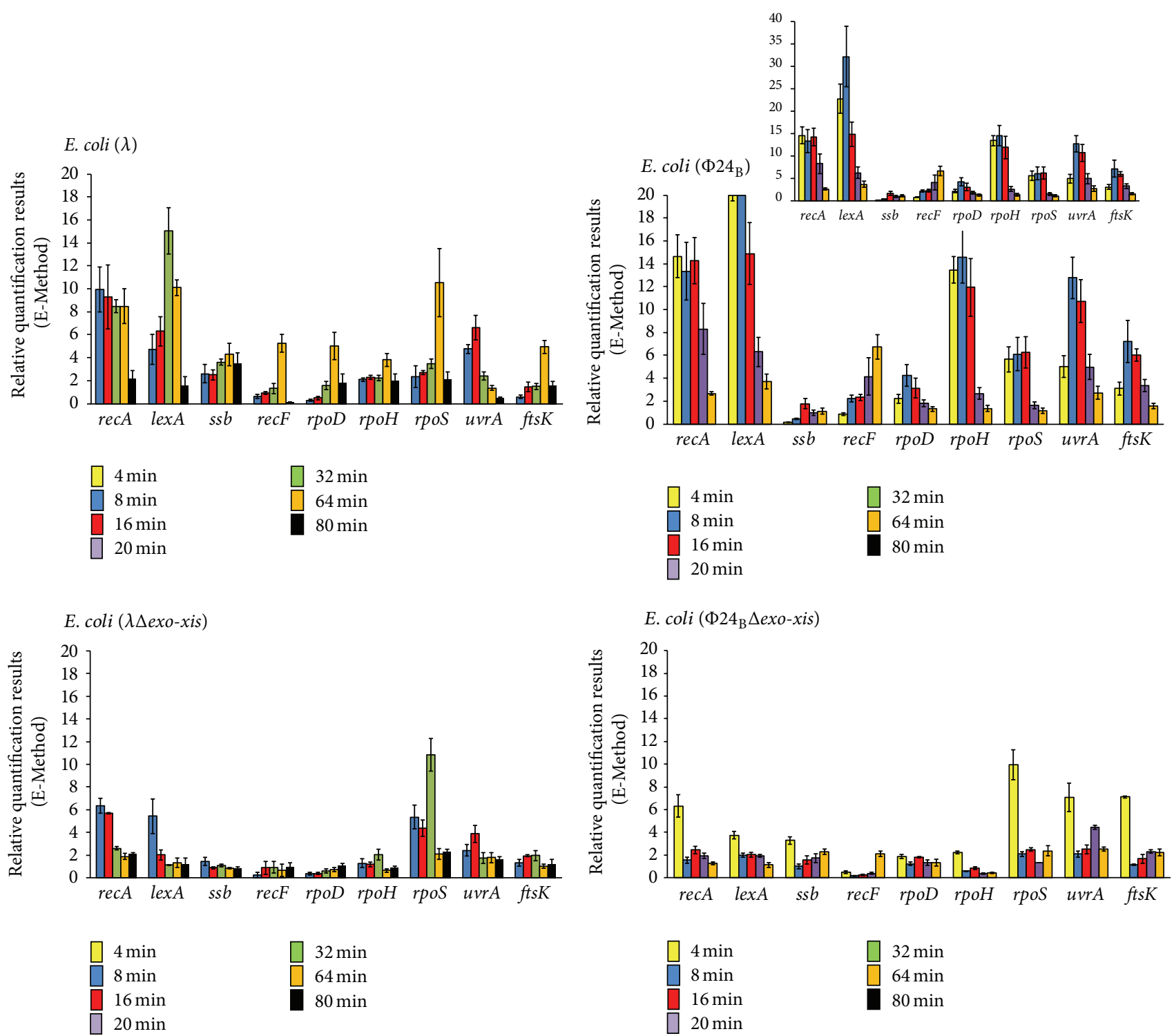

FIGURE 5: Expression of genes from the S.O.S. regulon in E. coli MG1655 lysogenic with $\lambda, \lambda \Delta e x o-x i s, \Phi 24_{\mathrm{B}}$, or $_{2} 24_{\mathrm{B}} \Delta e x o-x i s$, at indicated times after treatment with $1 \mathrm{mM} \mathrm{H}_{2} \mathrm{O}_{2}$, as estimated by reverse transcription quantitative real-time PCR. The values obtained with untreated cells were used as calibrators and were subtracted from the values determined at particular time points; thus, the presented values indicate the induction of expression of tested genes. The presented results are mean values from 3 independent experiments (biological samples), with error bars indicating SD. The additional panel for E. coli $\left(24_{\mathrm{B}}\right)$ represents the results with different scale.

mutant host, in the assays analogous to those presented in Figure $2, \mathrm{pfu} / \mathrm{mL}$ values were at the levels of those estimated for the uninduced controls $\left(1.8 \pm 0.1 \times 10^{2}, 4.1 \pm 1.4 \times 10^{2}\right.$, $1.3 \pm 0.1 \times 10^{3}$, and $2.8 \pm 0.3 \times 10^{3} \mathrm{pfu} / \mathrm{mL}$ for $\lambda, \lambda \Delta$ exo$x i s, \Phi 24_{\mathrm{B}}$, and $\Phi 24_{\mathrm{B}} \Delta$ exo-xis, resp.). Therefore, we conclude that induction of the investigated prophages under conditions of the oxidative stress (treatment with hydrogen peroxide) strongly depends on RecA function. Indeed, in cells lysogenic for $\lambda$ or $\Phi 24_{B}$ and treated with UV light or hydrogen peroxide, efficient induction of the S.O.S. response was evident, as estimated with the SOS ChromoTest (Figure 4). Intriguingly, while induction of the S.O.S. response by hydrogen peroxide in $\lambda \Delta$ exo-xis lysogen was comparable to that in $\lambda$ lysogen, the signal in the SOS ChromoTest in $\Phi 24_{\mathrm{B}} \Delta$ exo-xis lysogen was considerably weaker than in the analogous experiment with $\Phi 24_{\mathrm{B}}$ lysogen (Figure 4). No such difference could be observed in UV-irradiated bacteria (Figure 4).

3.3. Deletion of the Exo-Xis Region Negatively Influences Expression of Genes from the S.O.S. Regulon in Hydrogen Peroxide-Treated Lysogenic Bacteria. Since unexpected results were obtained in experiments with hydrogen peroxide-treated $\Phi 24_{\mathrm{B}} \Delta$ exo-xis lysogenic cells (Figure 4), we aimed to investigate the phenomenon of a less efficient induction of the S.O.S. response in more detail. Thus, expression of genes from the S.O.S. regulon was tested by reverse transcription quantitative real-time PCR in E. coli cells lysogenic for $\lambda, \lambda \Delta e x o-x i s, \Phi 24_{\mathrm{B}}$, and $\Phi 24_{\mathrm{B}} \Delta$ exo-xis 

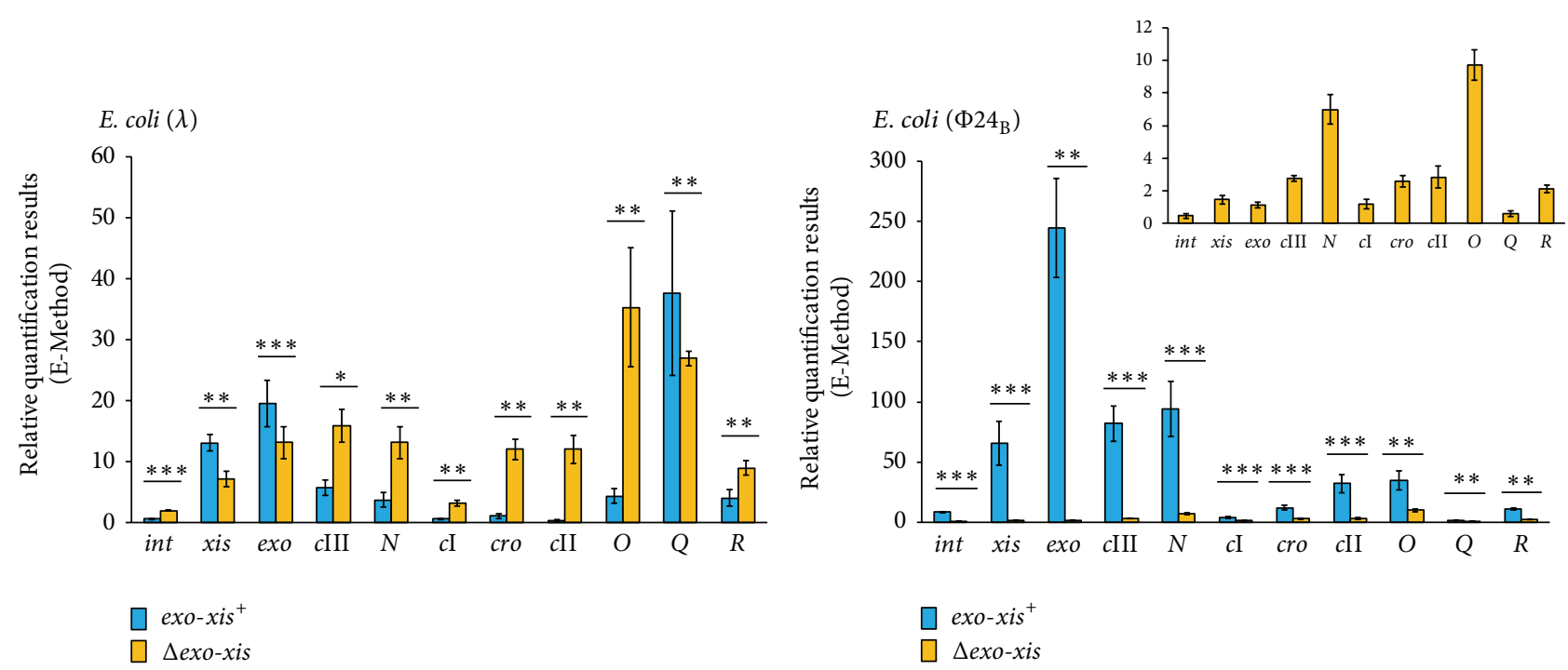

FIGURE 6: Expression of selected bacteriophage genes in E. coli MG1655 lysogenic with $\lambda$ or $\Phi 24_{\mathrm{B}}$, either wild-type (blue columns) or $\Delta$ exo-xis (yellow columns) at $160 \mathrm{~min}$ after treatment with $1 \mathrm{mM} \mathrm{H}_{2} \mathrm{O}_{2}$, as estimated by reverse transcription quantitative real-time PCR. The values obtained with untreated cells were used as calibrators and were subtracted from the values determined at particular time points; thus, the presented values indicate the induction of expression of tested genes. The presented results are mean values from 3 independent experiments (biological samples), with error bars indicating SD. The additional panel for E. coli $\left(24_{\mathrm{B}}\right)$ represents the results of $\Delta$ exo-xis variant with different scale, due to very small values measured. Statistically significant differences (in $t$-test) are marked as follows: ${ }^{*} p<0.05$, ${ }^{* *} p<0.01$, and ${ }^{* * *} p<0.001$

TABLE 4: Duration of the lag phase of the phage lytic development after prophage induction with either hydrogen peroxide $(1 \mathrm{mM})$ or UV irradiation $\left(50 \mathrm{~J} / \mathrm{m}^{2}\right)$.

\begin{tabular}{|c|c|c|}
\hline \multirow[t]{2}{*}{ Strain } & \multicolumn{2}{|c|}{$\begin{array}{l}\text { The time range of the switch from lag to } \\
\qquad \log \text { phase }\end{array}$} \\
\hline & $\mathrm{H}_{2} \mathrm{O}_{2}(1 \mathrm{mM})$ & $\mathrm{UV}\left(50 \mathrm{~J} / \mathrm{m}^{2}\right)$ \\
\hline MG1655 $(\lambda)$ & $60-90 \mathrm{~min}$ & $60 \mathrm{~min}$ \\
\hline MG1655 ( $\lambda \Delta$ exo-xis $)$ & $90-120 \mathrm{~min}$ & $30-60 \mathrm{~min}$ \\
\hline $\operatorname{MG1655}(\lambda \Delta o r f s)$ & $60-90 \mathrm{~min}$ & $30-60 \mathrm{~min}$ \\
\hline MG1655 $(\lambda \Delta o r f 60 a)$ & $60-90 \mathrm{~min}$ & $30-60 \mathrm{~min}$ \\
\hline MG1655 ( $\lambda \Delta$ orf63) & $60-90 \mathrm{~min}$ & $30-90 \mathrm{~min}$ \\
\hline MG1655 $(\lambda \Delta$ orf61) & $60-90 \mathrm{~min}$ & $30-60 \mathrm{~min}$ \\
\hline MG1655 ( $\lambda \Delta$ orf73) & $30-60 \mathrm{~min}$ & $0-30 \mathrm{~min}$ \\
\hline MG1655 ( $\lambda \Delta e a 22)$ & $60-90 \mathrm{~min}$ & $30-60 \mathrm{~min}$ \\
\hline MG1655 ( $\lambda \Delta e a 8.5)$ & $60-90 \mathrm{~min}$ & $30-60 \mathrm{~min}$ \\
\hline $\operatorname{MG1655}\left(\Phi 24_{\mathrm{B}}\right)$ & $60-90 \mathrm{~min}$ & $150-180 \mathrm{~min}$ \\
\hline MG1655 (Ф24 ${ }_{\mathrm{B}} \Delta$ exo-xis $)$ & a & $150-180 \mathrm{~min}$ \\
\hline MG1655 (Ф24 $\left.{ }_{\mathrm{B}} \Delta o r f s\right)$ & $150-180 \mathrm{~min}$ & $150-180 \mathrm{~min}$ \\
\hline MG1655 (Ф24 ${ }_{\mathrm{B}} \Delta$ orf60a $)$ & $120-150 \mathrm{~min}$ & $90-120 \mathrm{~min}$ \\
\hline MG1655 (Ф24 ${ }_{\mathrm{B}} \Delta$ orf63) & $120-150 \mathrm{~min}$ & $30-60 \mathrm{~min}$ \\
\hline MG1655 (Ф24 $\left.{ }_{B} \Delta o r f 61\right)$ & $90-120 \mathrm{~min}$ & $30-60 \mathrm{~min}$ \\
\hline $\operatorname{MG1655}\left(\Phi 24_{\mathrm{B}} \Delta o r f 73\right)$ & $90-120 \mathrm{~min}$ & $120-150 \mathrm{~min}$ \\
\hline $\operatorname{MG1655}\left(\Phi 24_{\mathrm{B}} \Delta e a 22\right)$ & $120-150 \mathrm{~min}$ & $30-60 \mathrm{~min}$ \\
\hline
\end{tabular}

${ }^{a}$ The value was not determined due to a very low efficiency of prophage induction under these conditions (as shown in Figure 2).

and treated with hydrogen peroxide. In both $\lambda$ and $\Phi 24_{B}$, deletion of the exo-xis region caused a significant reduction in the mRNA levels of most of the S.O.S. regulon genes relative to wild-type prophages, with exceptions of rpoS gene in both phages and $s s b, u v r A$, and ftsK genes in $\Phi 24_{\mathrm{B}}$, especially at later times after the treatment (Figure 5). Interestingly, in the case of wild-type $\Phi 24_{\mathrm{B}}$ lysogenic cells, the enhanced expression of particular genes from the S.O.S. regulon persisted longer, in most cases until $16 \mathrm{~min}$ after induction, whereas in the deletion mutant it decreases after 4 min (Figure 5). The impairment in expression of genes from the S.O.S. regulon (in particular recA and lexA genes, encoding the main regulators of the S.O.S. response) in the absence of the exo-xis region was more pronounced in $\Phi 24_{\mathrm{B}}$ than in $\lambda$. Moreover, induction of the S.O.S. regulon occurred significantly earlier in $\Phi 24_{\mathrm{B}}$ and $\Phi 24_{\mathrm{B}} \Delta$ exo-xis lysogens than in cells bearing $\lambda$ and $\lambda \Delta$ exo-xis prophages (Figure 5). These results might explain, at least partially, effects of deletions of exo-xis genes on prophage induction, demonstrated in Figure 2 and Table 4, particularly delayed induction of $\Phi 24_{B}$ prophage devoid of certain genes and open reading frames, and less pronounced effects of their lack in $\lambda$ than in $\Phi 24_{B}$.

Indications that overexpression of some genes from the exo-xis region of $\lambda$ can influence host cell cycle and DNA replication have been reported previously [21, 22]. Suggestions that some genes of $\Phi 24_{\mathrm{B}}$ prophage may affect host growth were also published [38]. However, the results described in this subsection demonstrate for the first time that the exo-xis region can significantly modulate one of global cellular responses, the S.O.S. response, after treatment with hydrogen peroxide.

3.4. Expression of Crucial Phage Genes Is Dramatically Decreased after Treatment of Lysogenic Cells with Hydrogen Peroxide in the Absence of the Exo-Xis Region in $\Phi 24_{\mathrm{B}}$ Prophage. Expression of phage genes, crucial for the 

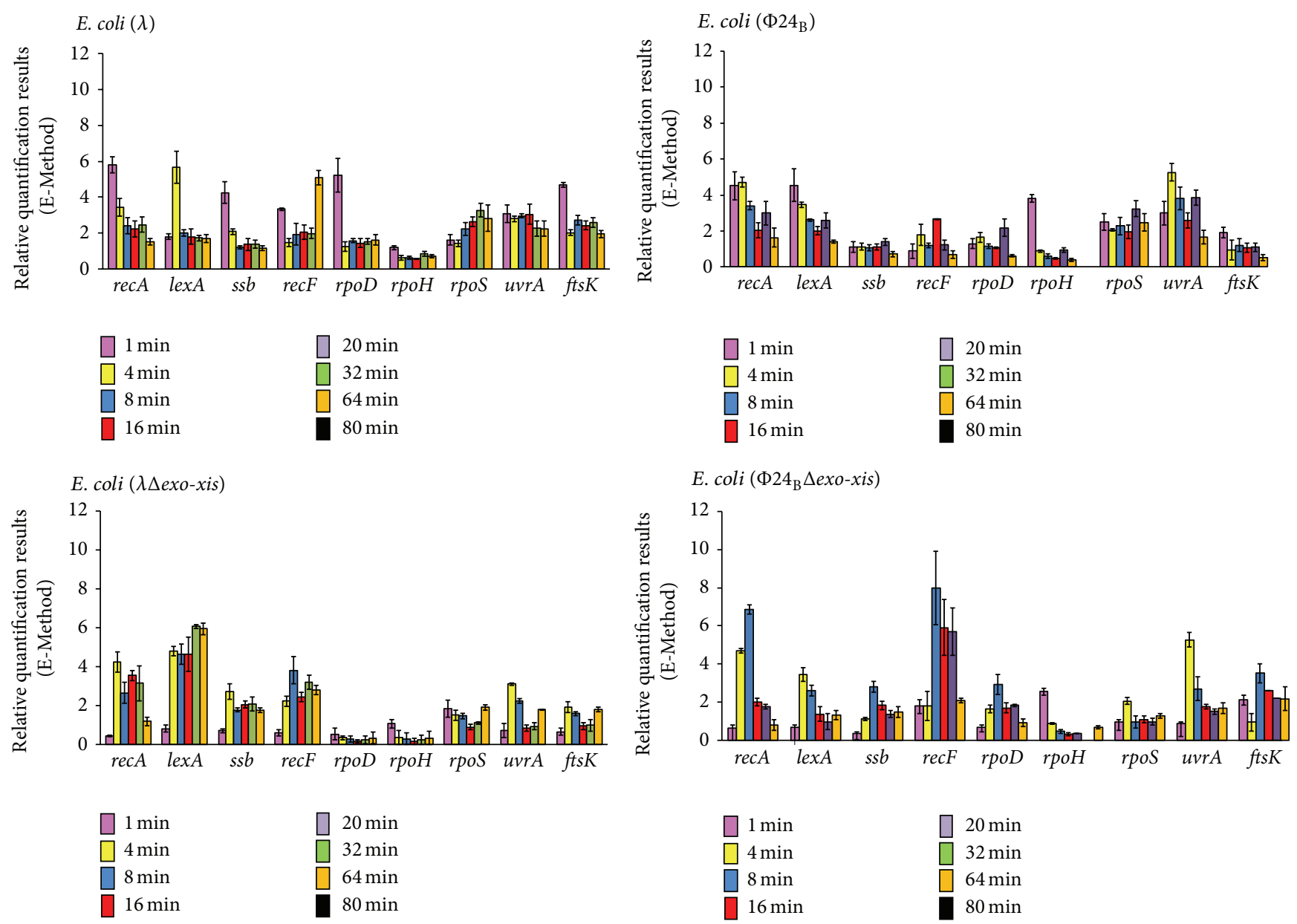

Figure 7: Expression of genes from the S.O.S. regulon in E. coli MG1655 lysogenic with $\lambda, \lambda \Delta e x o-x i s, \Phi 24_{\mathrm{B}}$, or $\Phi 24_{\mathrm{B}} \Delta e x o-x i s$, at indicated times after UV irradiation $\left(50 \mathrm{~J} / \mathrm{m}^{2}\right)$, as estimated by reverse transcription quantitative real-time PCR. The values obtained with untreated cells were used as calibrators and were subtracted from the values determined at particular time points; thus, the presented values indicate the induction of expression of tested genes. The presented results are mean values from 3 independent experiments (biological samples), with error bars indicating SD.

regulatory processes and lytic development, has been tested under the same conditions as described in the preceding subsection. The specific conditions and time after addition of hydrogen peroxide into the cell culture at which samples were withdrawn were chosen on the basis of similar experiments reported previously [26]. Interestingly, different effects of the deletion of the exo-xis region were observed for phages $\lambda$ and $24_{\mathrm{B}}$. In $\lambda$, deletion of genes and open reading frames located between exo and xis genes did not cause considerable effects on mRNA levels for xis, exo, and $Q$, whereas expression of int, $c \mathrm{III}, \mathrm{N}, c \mathrm{I}, c r o, c \mathrm{II}, \mathrm{O}$, and $R$ was enhanced upon treatment with hydrogen peroxide (Figure 6). Completely different results were obtained when $\Phi 24_{\mathrm{B}}$ and $\Phi 24_{\mathrm{B}} \Delta$ exo-xis lysogens were studied; namely, expression of all tested genes was drastically impaired in hydrogen peroxide-treated bacteria in the absence of the exo-xis region on the prophage (Figure 6).

While negative regulation of transcription from cIIdependent promoters by overexpression of the exo-xis region has been reported previously in phage $\lambda$ [23], this study demonstrated for the first time significant effects of this region on expression of a battery of phage genes under conditions of the oxidative stress. The results presented in Figure 6 for phage $\lambda$ are compatible with those published previously (though obtained with different methods) [23], as overexpression of the exo-xis region had opposite effects to those observed in its absence. On the other hand, severely impaired expression of all tested phage genes in $\Phi 24_{\mathrm{B}} \Delta$ exo$x i s$ was unexpected. However, these results (Figure 6) can explain a strong defect in the induction of $\Phi 24_{\mathrm{B}} \Delta$ exoxis prophage (and perhaps further lytic development) by hydrogen peroxide (Figure 2). Similarly, drastic differences between effects of $\Delta$ exo-xis mutations on hydrogen peroxidemediated prophage induction between $\lambda$ and $24_{\mathrm{B}}$ (Figure 2) can be ascribed to opposite regulation of expression of phage genes in the absence of the exo-xis region.

\subsection{Effects of the Exo-Xis Region on Expression of Host and} Phage Gene in UV-Irradiated Lysogenic Cells. Experiments analogous to those described in two preceding subsections were performed with lysogenic cells irradiated with UV. 

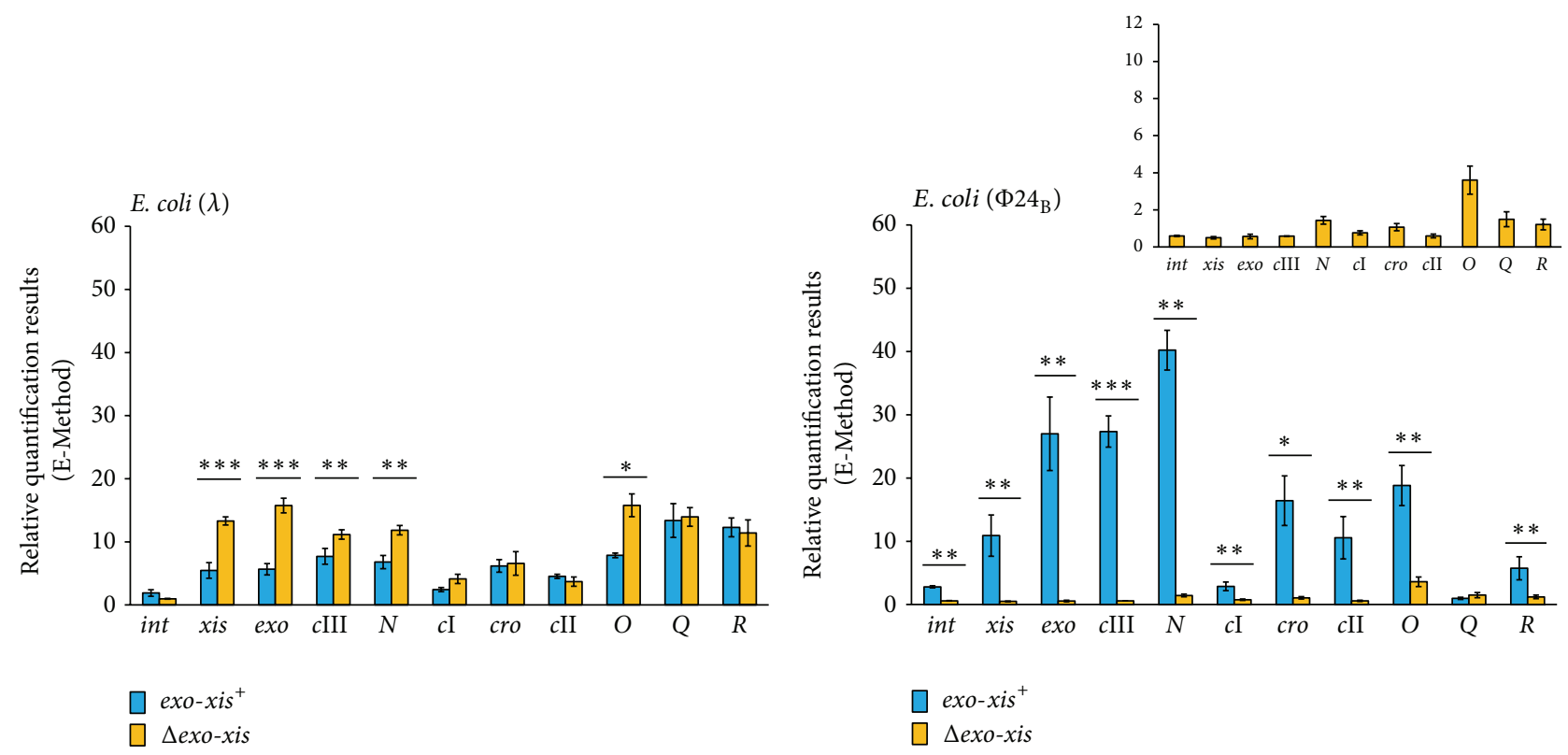

FIGURE 8: Expression of selected bacteriophage genes in E. coli MG1655 lysogenic with $\lambda$ or $\Phi 24_{\mathrm{B}}$, either wild-type (blue columns) or $\Delta$ exo$x$ is (yellow columns) at $160 \mathrm{~min}$ after UV irradiation $\left(50 \mathrm{~J} / \mathrm{m}^{2}\right)$, as estimated by reverse transcription quantitative real-time PCR. The values obtained with untreated cells were used as calibrators and were subtracted from the values determined at particular time points; thus, the presented values indicate the induction of expression of tested genes. The presented results are mean values from 3 independent experiments (biological samples), with error bars indicating SD. The additional panel for E. coli $\left(24_{\mathrm{B}}\right)$ represents the results of $\Delta$ exo-xis variant with different scale, due to very small values measured. Statistically significant differences (in $t$-test) are marked as follows: ${ }^{*} p<0.05$, ${ }^{* *} p<0.01$, and ${ }^{* * *} p<0.001$.

Interestingly, in both $\lambda$ and $24_{\mathrm{B}}$ phages, deletion of the exoxis region caused only moderate effects on expression of most genes from the S.O.S. regulon (Figure 7), contrary to hydrogen peroxide-treated bacteria where the differences were significantly higher (compare Figures 5 and 7). The exceptions in UV-irradiated cells were $r p o D, r p o H$, and $r p o S$ genes in $\lambda$ and $r p o H$ and $r p o S$ in $24_{\mathrm{B}}$, whose expressions were at considerably lower level in the absence of the exo-xis region (Figure 7). One should also note that the induction of the S.O.S. regulon with UV irradiation was quicker than that with hydrogen peroxide. These results indicate that the influence of the exo-xis region on the S.O.S. response is particularly well pronounced under conditions of the oxidative stress.

Unlike the S.O.S. regulon expression, levels of mRNAs of bacteriophage genes in UV-irradiated cells were affected similarly to those in hydrogen peroxide-treated lysogenic bacteria by the absence of the exo-xis region (Figure 8). Again, although some differences were observed between $\lambda$ and $\lambda \Delta$ exo-xis, the differences between $\Phi 24_{\mathrm{B}}$ and $\Phi 24_{\mathrm{B}} \Delta$ exo-xis were dramatic. This indicates that the influence of the exo-xis region on expression of phage genes after prophage induction does not depend on the induction agent.

\section{Conclusions}

The exo-xis region is necessary for effective, RecA-dependent induction of Shiga toxin-converting bacteriophage $\Phi 24_{\mathrm{B}}$ under conditions of the oxidative stress. In hydrogen peroxide-treated E. coli, this region positively influences expression of the S.O.S. regulon in both $\Phi 24_{B}$ and $\lambda$ lysogens and expression of phage genes crucial for lytic development (particularly xis, exo, $N$, cro, $O, Q$, and $R$ ) in $\Phi 24_{\mathrm{B}}$, but not in $\lambda$. Since the oxidative stress appears to be the major cause of induction of Shiga toxin-converting prophages during infections of human intestine by enterohemorrhagic $E$. coli (EHEC), the exo-xis region and/or products of its expression might be considered as potential targets for anti-EHEC drugs.

\section{Conflict of Interests}

The authors declare no conflict of interests.

\section{Authors' Contribution}

Katarzyna Licznerska and Aleksandra Dydecka contributed equally to this work.

\section{Acknowledgment}

This work was supported by the National Science Center (Poland) Grant no. 2013/09/B/NZ2/02366 to Alicja Węgrzyn.

\section{References}

[1] C. L. Gyles, "Shiga toxin-producing Escherichia coli: an overview," Journal of Animal Science, vol. 85, no. 13, supplement, pp. E45-E62, 2007.

[2] J. M. Hunt, "Shiga toxin-producing Escherichia coli (STEC)," Clinics in Laboratory Medicine, vol. 30, no. 1, pp. 21-45, 2010. 
[3] S. Razzaq, "Hemolytic uremic syndrome: an emerging health risk," American Family Physician, vol. 74, no. 6, pp. 991-998, 2006.

[4] D. Law, "Virulence factors of Escherichia coli O157 and other Shiga toxin-producing E. coli," Journal of Applied Microbiology, vol. 88 , no. 5, pp. 729-745, 2000.

[5] L. Beutin and A. Martin, "Outbreak of shiga toxin-producing Escherichia coli (STEC) O104:H4 infection in Germany causes a paradigm shift with regard to human pathogenicity of STEC strains," Journal of Food Protection, vol. 75, no. 2, pp. 408-418, 2012.

[6] S. K. Bloch, A. Felczykowska, and B. Nejman-Falenczyk, "Escherichia coli O104:H4 outbreak-have we learnt a lesson from it?” Acta Biochimica Polonica, vol. 59, no. 4, pp. 483-488, 2012.

[7] H. Karch, E. Denamur, U. Dobrindt et al., "The enemy within us: lessons from the 2011 European Escherichia coli O104:H4 outbreak," EMBO Molecular Medicine, vol. 4, no. 9, pp. 841-848, 2012.

[8] C. R. Laing, Y. Zhang, M. W. Gilmour et al., "A comparison of Shiga-toxin 2 bacteriophage from classical enterohemorrhagic Escherichia coli serotypes and the German E. coli O104:H4 outbreak strain," PLoS ONE, vol. 7, no. 5, Article ID e37362, 2012.

[9] A. Mellmann, D. Harmsen, C. A. Cummings et al., "Prospective genomic characterization of the german enterohemorrhagic Escherichia coli O104:H4 outbreak by rapid next generation sequencing technology," PLoS ONE, vol. 6, no. 7, Article ID e22751, 2011.

[10] D. Werber, G. Krause, C. Frank et al., "Outbreaks of virulent diarrheagenic Escherichia coli-are we in control?" BMC Medicine, vol. 10, article 11, 2012.

[11] H. E. Allison, "Stx-phages: drivers and mediators of the evolution of STEC and STEC-like pathogens," Future Microbiology, vol. 2, no. 2, pp. 165-174, 2007.

[12] J. M. Loś, M. Loś, and G. Wegrzyn, "Bacteriophages carrying Shiga toxin genes: genomic variations, detection and potential treatment of pathogenic bacteria," Future microbiology, vol. 6, no. 8, pp. 909-924, 2011.

[13] M. Ptashne, A Genetic Switch: Phage Lambda Revisited, Cold Spring Harbor Laboratory Press, Cold Spring Harbor, NY, USA, 3rd edition, 2004.

[14] G. Wegrzyn and A. Wegrzyn, "Genetic switches during bacteriophage $\lambda$ development," Progress in Nucleic Acid Research and Molecular Biology, vol. 79, pp. 1-48, 2005.

[15] G. Węgrzyn, K. Licznerska, and A. Węgrzyn, "Phage $\lambda$-new insights into regulatory circuits," Advances in Virus Research, vol. 82, pp. 155-178, 2012.

[16] L. Imamovic and M. Muniesa, "Characterizing RecAindependent induction of Shiga toxin2-encoding phages by EDTA treatment," PLoS ONE, vol. 7, no. 2, Article ID e32393, 2012.

[17] J. M. Łoś, M. Łoś, A. Węgrzyn, and G. Węgrzyn, "Altruism of Shiga toxin-producing Escherichia coli: recent hypothesis versus experimental results," Frontiers in Cellular and Infection Microbiology, vol. 2, article 166, 2013.

[18] P. L. Wagner, D. W. K. Acheson, and M. K. Waldor, "Human neutrophils and their products induce Shiga toxin production by enterohemorrhagic Escherichia coli," Infection and Immunity, vol. 69, no. 3, pp. 1934-1937, 2001.

[19] J. M. Łoś, M. Łoś, G. Węgrzyn, and A. Węgrzyn, "Differential efficiency of induction of various lambdoid prophages responsible for production of Shiga toxins in response to different induction agents," Microbial Pathogenesis, vol. 47, no. 6, pp. 289298, 2009.

[20] J. M. Łoś, M. Łoś, A. Wȩgrzyn, and G. Wẹgrzyn, “Hydrogen peroxide-mediated induction of the Shiga toxin-converting lambdoid prophage ST2-8624 in Escherichia coli O157:H7," FEMS Immunology and Medical Microbiology, vol. 58, no. 3, pp. 322-329, 2010.

[21] P. Kourilsky and A. Knapp, "Lysogenization by bacteriophage lambda. III.-multiplicity dependent phenomena occuring upon infection by lambda," Biochimie, vol. 56, no. 11-12, pp. 1517$1523,1975$.

[22] K. Sergueev, D. Court, L. Reaves, and S. Austin, "E. coli cell-cycle regulation by bacteriophage $\lambda$," Journal of Molecular Biology, vol. 324, no. 2, pp. 297-307, 2002.

[23] J. M. Łoś, M. Łoś, A. Węgrzyn, and G. Węgrzyn, "Role of the bacteriophage $\lambda$ exo-xis region in the virus development," Folia Microbiologica, vol. 53, no. 5, pp. 443-450, 2008.

[24] S. Bloch, B. Nejman-Faleńczyk, J. M. Łoå et al., "Genes from the exo-xis region of $\lambda$ and Shiga toxin-converting bacteriophages influence lysogenization and prophage induction," Archives of Microbiology, vol. 195, no. 10-11, pp. 693-703, 2013.

[25] J. J. Kwan, E. Smirnova, S. Khazai, F. Evanics, K. L. Maxwell, and L. W. Donaldson, "The solution structures of two prophage homologues of the bacteriophage $\lambda$ Ea 8.5 protein reveal a newly discovered hybrid homeodomain/zinc-finger fold," Biochemistry, vol. 52, no. 21, pp. 3612-3614, 2013.

[26] S. Bloch, B. Nejman-Faleńczyk, A. Dydecka et al., "Different expression patterns of genes from the Exo-Xis region of bacteriophage $\lambda$ and Shiga toxin-converting bacteriophage $\Phi 24_{B}$ following infection or prophage induction in Escherichia coli," PLoS ONE, vol. 9, no. 10, Article ID e108233, 2014.

[27] K. F. Jensen, “The Escherichia coli K-12 'wild types' W3110 and MG1655 have an rph frameshift mutation that leads to pyrimidine starvation due to low pyrE expression levels," Journal of Bacteriology, vol. 175, no. 11, pp. 3401-3407, 1993.

[28] H. E. Allison, M. J. Sergeant, C. E. James et al., "Immunity profiles of wild-type and recombinant Shiga-like toxin-encoding bacteriophages and characterization of novel double lysogens," Infection and Immunity, vol. 71, no. 6, pp. 3409-3418, 2003.

[29] B. Nejman-Faleńczyk, S. Bloch, K. Licznerska et al., "A small, microRNA-size, ribonucleic acid regulating gene expression and development of Shiga toxin-converting bacteriophage Ф24 B," Scientific Reports, vol. 5, Article ID 10080, 2015.

[30] J. M. Łoś, P. Golec, G. Wȩgrzyn, A. Wȩgrzyn, and M. Łoś, "Simple method for plating Escherichia coli bacteriophages forming very small plaques or no plaques under standard conditions," Applied and Environmental Microbiology, vol. 74, no. 16, pp. 5113-5120, 2008.

[31] P. Quillardet, O. Huisman, R. D’Ari, and M. Hofnung, "SOS chromotest, a direct assay of induction of an SOS function in Escherichia coli K-12 to measure genotoxicity," Proceedings of the National Academy of Sciences of the United States of America, vol. 79, no. 19, pp. 5971-5975, 1982.

[32] F. Fish, I. Lampert, and A. Halachmi, "The SOS chromotest kit: a rapid method for the detection of genotoxicity," Toxicity Assessment, vol. 2, no. 2, pp. 135-147, 1987.

[33] A. Herman-Antosiewicz and G. Wȩgrzyn, "Regulation of copy number and stability of phage $\lambda$ derived pTC $\lambda 1$ plasmid in the light of the dimer/multimer catastrophe hypothesis," FEMS Microbiology Letters, vol. 176, no. 2, pp. 489-493, 1999.

[34] E. Strauch, J. A. Hammerl, A. Konietzny et al., "Bacteriophage 2851 is a prototype phage for dissemination of the Shiga toxin 
variant gene 2c in Escherichia coli O157:H7,' Infection and Immunity, vol. 76, no. 12, pp. 5466-5477, 2008.

[35] D. Nowicki, S. Bloch, B. Nejman-Faleńczyk, A. SzalewskaPałasz, A. Węgrzyn, and G. Węgrzyn, "Defects in RNA polyadenylation impair both lysogenization by and lytic development of Shiga toxin-converting bacteriophages," Journal of General Virology, vol. 96, no. 7, pp. 1957-1968, 2015.

[36] R. D. Finn, A. Bateman, J. Clements et al., "Pfam: the protein families database," Nucleic Acids Research, vol. 42, no. 1, pp. D222-D230, 2014.

[37] A. P. Koudelka, L. A. Hufnagel, and G. B. Koudelka, "Purification and characterization of the repressor of the shiga toxinencoding bacteriophage 933W: DNA binding, gene regulation, and autocleavage," Journal of Bacteriology, vol. 186, no. 22, pp. 7659-7669, 2004.

[38] L. M. Riley, M. Veses-Garcia, J. D. Hillman, M. Handfield, A. J. McCarthy, and H. E. Allison, "Identification of genes expressed in cultures of $E$. coli lysogens carrying the Shiga toxin-encoding prophage Ф24B," BMC Microbiology, vol. 12, article 42, 2012. 


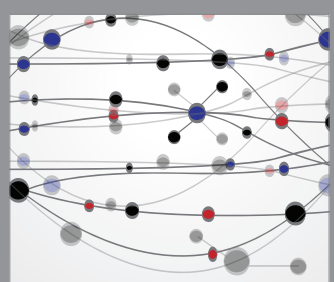

The Scientific World Journal
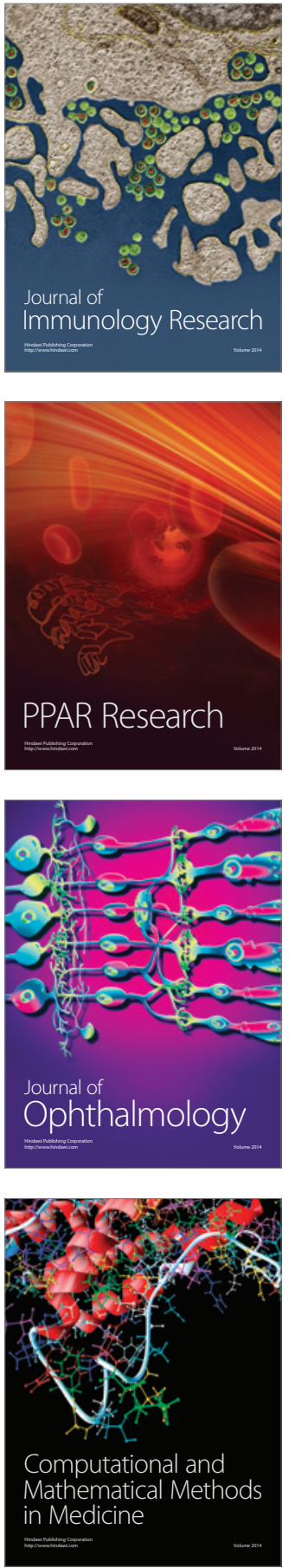

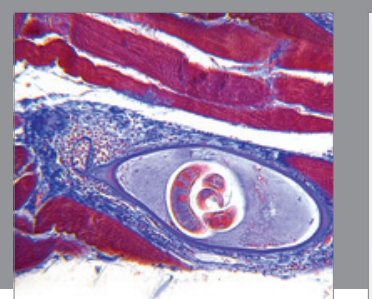

Gastroenterology Research and Practice

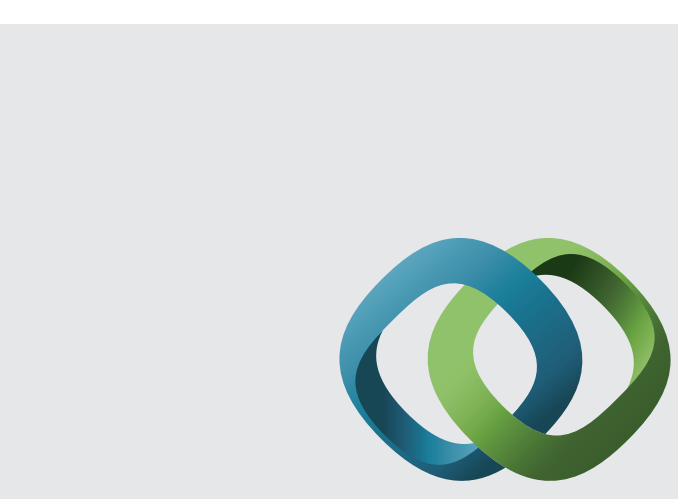

\section{Hindawi}

Submit your manuscripts at

http://www.hindawi.com
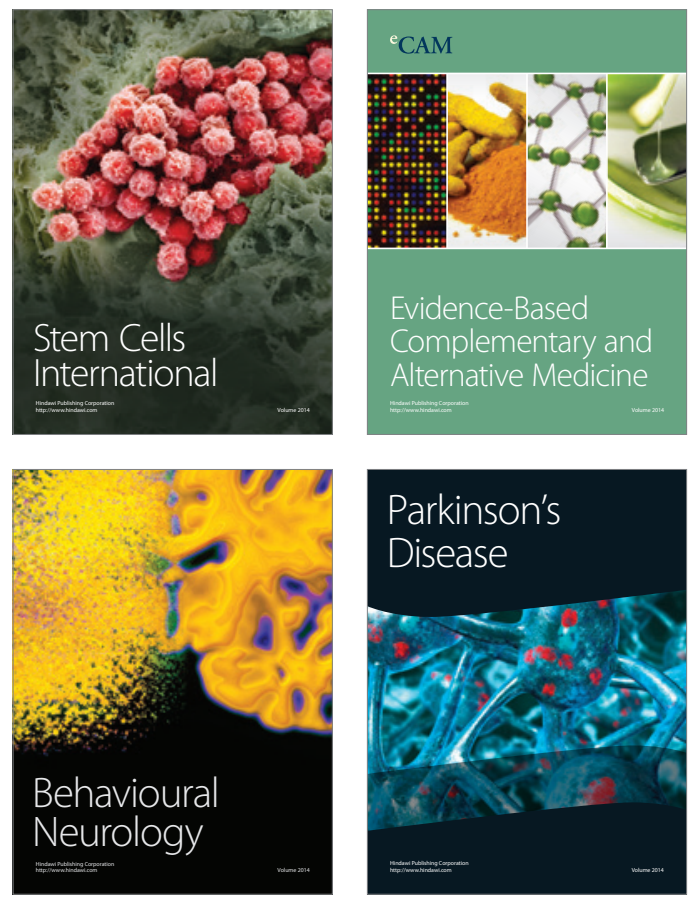
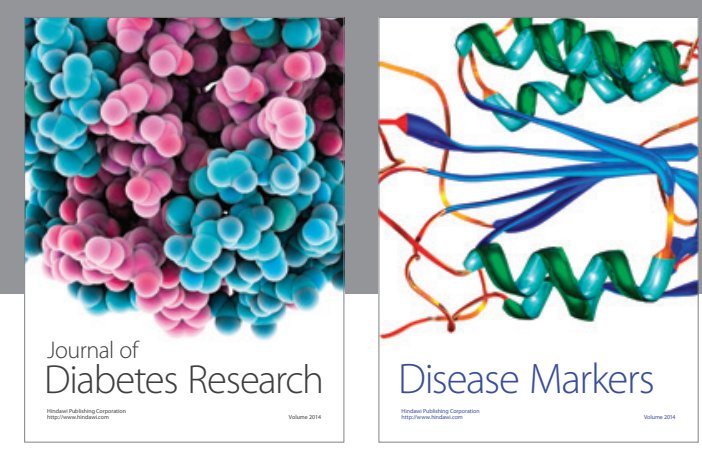

Disease Markers
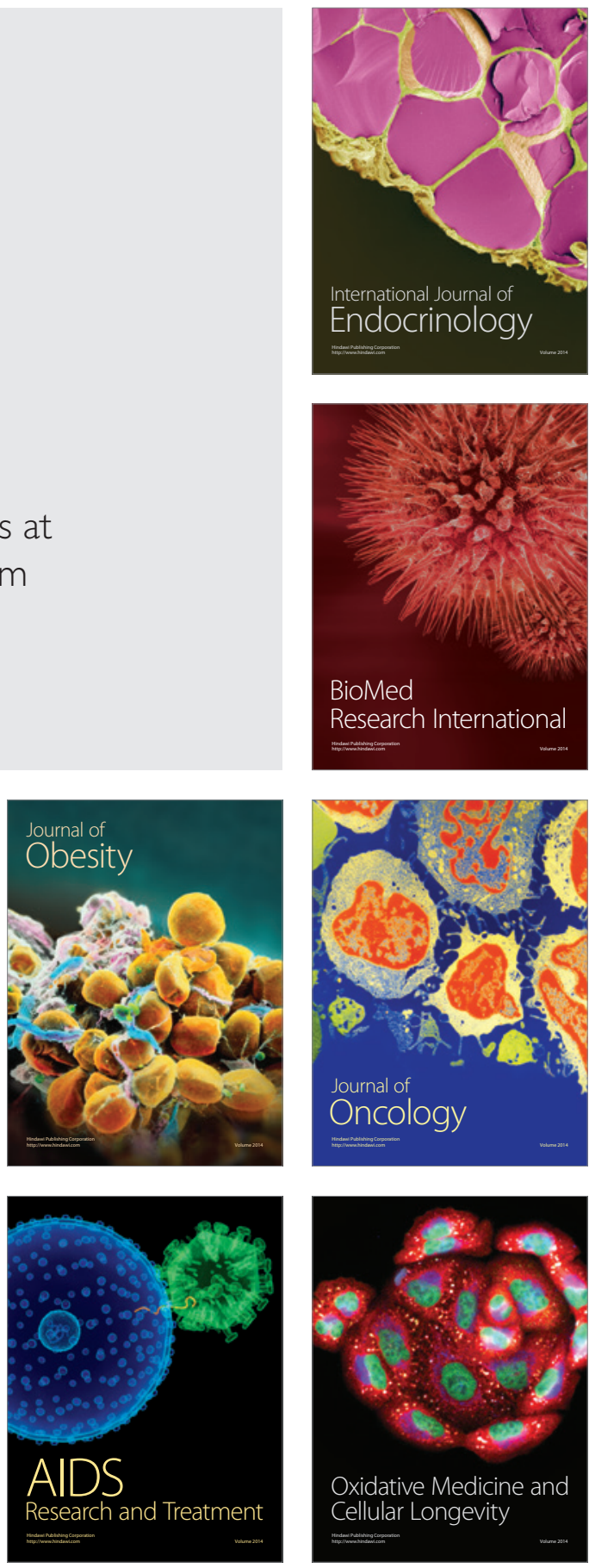